\title{
Editorial for Special Issue of SPAR: The Vanguard Method in a Systems Thinking Context
}

\author{
Brendan O’Donovan
}

Published online: 5 December 2012

(C) Springer Science+Business Media, LLC 2012

Since being first developed by Professor John Seddon and his colleagues in the mid-1980s, the Vanguard Method has evolved as a way to study and redesign the work of service operations. Seddon's published works $(2003,2008)$ have described the Vanguard Method in detail, and there are already numerous documented examples of its application to organisations (ODPM 2005; Middleton 2010; Zokaei et al. 2010). It has many features in common with other forms of systems thinking as developed by thinkers such as Checkland, Ackoff, Senge and Jackson (ODPM 2005). Some of these shared systems concepts are explored in this editorial paper. This editorial then introduces the other articles which appear here in this special issue of SPAR.

Seddon's work has been categorised as a version of systems thinking by both himself (Seddon 2008) and others (Jackson et al. 2007). The Vanguard approach starts with the situations that people find themselves in, where their current thinking and practices are exposed to them by a structured method for studying 'the way the work works' (Seddon 2003, p 14). This frequently shows their organisation to be producing sub-optimal results for the service user. The method then leads workers to proceed with a collaborative inquiry in order to articulate a new purpose from the service user's perspective, before going on to co-design a system which can achieve this newly articulated purpose. Some of the features which are common to both the Vanguard Method and other forms of systems thinking (ST) are listed below:

- the problems which managers appear to have are not to be directly solved, but instead are to be 'dissolved' (Ackoff 1999b)

- ST situates itself in contrast to reductionism (what Seddon terms "command and control') (Chapman 2004)

- the parts of the system are recognised to be interdependent with emergent properties (Checkland 1997; Flood 1999)

- $\quad$ ST is best learnt experientially (Ison 2010)

- an emphasis is placed on defining and working to the system's purpose (Open University 1999)

B. O'Donovan $(\bowtie)$

Vanguard Consulting, Buckingham, UK

e-mail: brendan@vanguardconsult.co.uk 
- ST involves the idea of people being exposed to their own 'worldview' or 'Weltanschauung' (Churchman 1968) and recognising that this contrasts with the experience of their service from a customer's perspective

- feedback loops are demonstrated to be crucial to refining a system's performance (Senge 2006)

- services need to structure themselves to be able to deal with the 'requisite variety' of their operating environments (Ashby 1958)

This paper will explore the elements which Seddon's ideas have in common with other systems thinkers. In addition, Seddon's version of systems thinking is unusual because of the particular attention given to the ideas of Deming $(1982,1994)$ and Ohno (1988) who are not customarily considered to be part of the systems thinking literature (ODPM 2005; Seddon and Caulkin 2007). Both were major contributors to what has been described as the 'Japanese miracle' (Tuckman 1994), the remarkable reconstruction of the post-war Japanese economy. The article will also consider on what basis the claims are made for these management pioneers to be systems thinkers and therefore what effect these unorthodox systems influences have had on the Vanguard Method.

\section{Brief Outline of the Vanguard Method}

The Vanguard Method follows Seddon's 'Check-Plan-Do' cycle (see Fig. 1).

The first stage involves studying the work in a service organisation as a system, which Seddon calls the 'Check' stage (Seddon 2008, p 79). If a system is to be (re)designed against the demands being placed on the service by users, Seddon argues that the steps documented in the Check process will ensure that all involved are starting from a position where they can understand 'the way the work works' (Seddon 2003, p 14). The model for Check (Fig. 2, below) gives a structured way of understanding transactional services from the customer's point of view and is defined as an analysis of the 'what and why' of the current system (Jackson et al. 2008, p 3).

It primarily involves a team of workers and managers who represent the frontline of that service's delivery studying for themselves:

1. the purpose of the system as seen from the point of view of the service user

2. the demands placed upon the service at the points of transaction

3. the capability of the service to deliver against those demands

4. the steps taken in the flow of the work through the system

Fig. 1 'Check-Plan-Do' cycle. Seddon's Vanguard Method for service organisations (Seddon 2003, p 110)

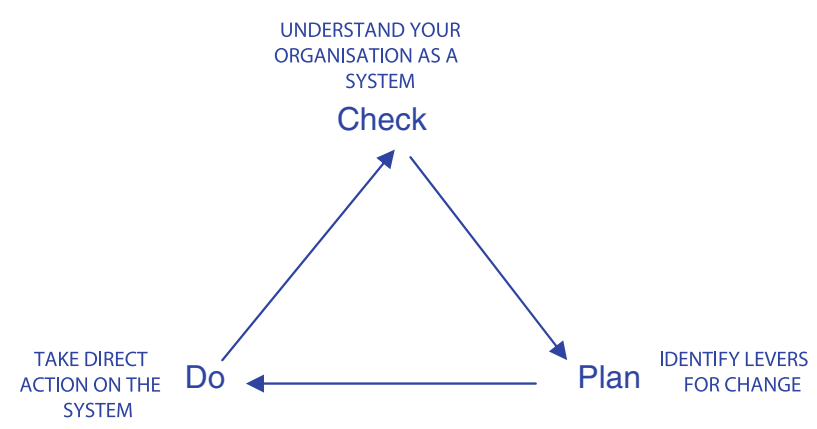




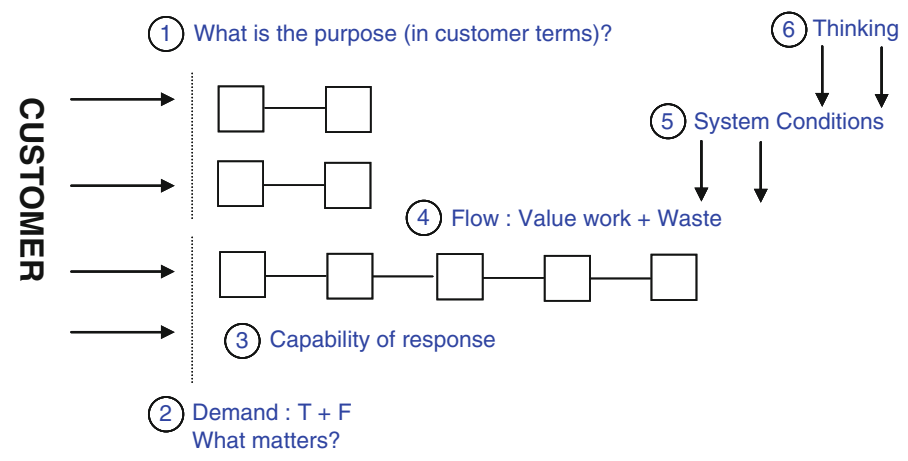

Fig. 2 The Vanguard model for Check (Seddon 2003, p 112)

5. the 'system conditions,' the things which explain why the system behaves in the way it does

6. the 'thinking' in the organisation - the management assumptions which have created the system conditions

Going through this process of structured data collection helps to build a picture of the system which describes the service as experienced by the end user/customer. Following Seddon's 'Purpose-Measures-Method' logic (see Fig. 4 below), the system is always discovered to be delivering against a purpose, no matter whether or not the purpose of the system has previously been articulated. Often, the Check process uncovers that the system is delivering to a de facto purpose which in fact undermines the purpose of the service as it would be articulated by a service user. Once the Check process has been completed, the senior managers in the organisation have to decide whether to proceed with experimentation in order to develop a new way of working (the 'Plan' stage). The final stage is to then make this new way of working the normal in the organisation (the 'Do' stage).

This editorial will cover some of the features shared by both the Vanguard Method and other forms of systems thinking, including those of Taiichi Ohno and W. Edwards Deming. It will then address some of the criticisms levelled at the Vanguard approach before introducing some of the papers which will make up the special issue of this journal.

\section{What is 'Systems Thinking'?}

As is often the case when attempting to outline the taxonomy of a particular set of ideas, it is perhaps most useful to start by defining what systems thinking isn't. In this case, systems thinking isn't reductionism. In a pamphlet for the UK think-tank Demos, Jake Chapman outlined the difference between reductionist and systems thinking:

The essential aspect of the reductionist approach is that complexity is simplified by dividing a problem into sub-problems or lesser components. The process of subdivision is continued until the resulting bits are simple enough to be analysed and understood. The operation of the original complex entity is then reconstructed from the operation of the components. But herein lies a potential problem. What if essential features of that entity are embedded not in the components but in their interconnectedness? What if its complexity arises from the ways in which its 
components actually relate to and interact with one another? The very act of simplifying by sub-division loses the interconnections and therefore cannot tackle this aspect of complexity. (Chapman 2004, p 35)

Difficulties occur for conventional management approaches based on reductionism when they are faced with complex, real-world problems, involving human beings (Checkland 1981). These are exactly the type of problems that managers and policy makers encounter in organisations. As Flood (1999, p 6) says '[Reductionism] has struggled primarily because it misunderstands the nature of human beings (yet it remains a dominant wisdom).' This reductionist form of thinking is therefore contrasted with systems thinking, which adopts a fundamentally different analysis, focussing on the inter-relationship between the different elements in a situation:

(B)y retaining the connections and avoiding the tendency to break things down, systems thinking provides a holistic approach to understanding and managing complexity (Chapman 2004, pp 35-6).

Recognising this interconnectedness, Checkland (1981, p 4) says:

Systems thinking, then, make conscious use of the particular concept of wholeness captured in the word 'system,' to order our thoughts.

Flood (1999, p 2) states:

We can only meaningfully understand ourselves by contemplating the whole of which we are an integral part. Systemic thinking is the discipline which makes visible that our actions are interrelated to other people's actions in patterns of behaviour and are not merely isolated events.

Capra (1996), cited in the ODPM report on systems thinking in housing (2005), said:

The more we study the major problems of our time, the more we come to realise that they cannot be understood in isolation. They are systemic problems, which means that they are interconnected and interdependent

Seddon's work is concerned with the design and management of service organisations. It is in this context that he recognises that a systems approach is the best way of dealing with the complexity of customer demands. The Vanguard Method provides a systematic way to take this systemic view of a service. Along the way, taking a customer-centred view of the organisation entails contrasting one's current understanding of how to view the design and management of the work with a reductionist 'command and control' logic. Seddon shows these two contrasting management logics in the form of a table:

Command and control thinking

Vanguard's systems thinking

Top-down, hierarchy

Functional specialisation

Separated from work

Output, target
to budget

$\begin{array}{ll}\text { Perspective } & \text { Outside-in, system } \\ \text { Design } & \text { Demand, value and flow } \\ \begin{array}{c}\text { Decision- } \\ \text { making }\end{array} & \text { Integrated with work } \\ \text { Measurement } & \begin{array}{c}\text { Capability, variation: } \\ \text { related to purpose }\end{array}\end{array}$


Table continued

\begin{tabular}{|c|c|c|}
\hline \multicolumn{2}{|l|}{ Command and control thinking } & \multirow{2}{*}{$\begin{array}{l}\text { Vanguard's systems thinking } \\
\text { What matters? }\end{array}$} \\
\hline Contractual & $\begin{array}{l}\text { Attitude to } \\
\text { customers }\end{array}$ & \\
\hline Contractual & $\begin{array}{r}\text { Attitude to } \\
\text { suppliers }\end{array}$ & Co-operation and mutuality \\
\hline Manage budgets and the people & $\begin{array}{l}\text { Role of } \\
\text { Management }\end{array}$ & $\begin{array}{l}\text { Act on the system and manage } \\
\text { against the purpose }\end{array}$ \\
\hline Control & Ethos & Learning \\
\hline Reactive. Change by project/initiative & $\begin{array}{l}\text { Approach to } \\
\text { change }\end{array}$ & Adaptive, integral, emergent \\
\hline Extrinsic & Motivation & Intrinsic \\
\hline
\end{tabular}

Table taken from Seddon (2003), p 11

Seddon's work is aimed at service organisations that wish to find 'a better way to make the work work' (Seddon 2003). Once the true purpose of a system has been uncovered through studying a service from a customer's point of view, the organisation can then be redesigned to incorporate systems principles. Major contributions to what has been characterised as the 'command and control' conventional approach to management can be traced back in a lineage from the 'scientific management' (Taylor 1998) movement, or from the adaptation of similar methods to mass production in the automotive industries (of Ford, Sloan, etc. see Seddon 2003; Womack et al. 2007). Command and control leads managers to be inward-looking, breaking down the different demands of customers into separate corporate functions and managing down through the hierarchy with targets. Journalist and author Simon Caulkin uses this memorable phrase from Jack Welch to describe the consequences for the focus of the organisation:

The opposite of top-down is not bottom-up, but outside-in. General Electric's Jack Welch once defined hierarchical organisations as places in which "everyone has their face toward the CEO and their ass toward the customer" (Caulkin 2010, p 10).

Seddon and Caulkin define 'command and control' management thus:

Command and control means regulation by management, with its battery of computer and other informational aids ... where decision-making is distant from the work and based on abstracted measures, budgets and plans (Seddon and Caulkin 2007)

Many of these aspects of management and organisational design are so deeply pervasive within conventional Western management practice as to appear invisible to most analysts. In contrast, Seddon believes these features are now preventing organisations from improving:

The issue is not that command and control was without value, for it solved problems for each of these management pioneers [e.g. Taylor, Ford, Sloan] in new ways. But we have not continued to learn; the basic precepts of command and control are unquestioned although the underlying paradigm has outlived its usefulness. (Seddon 2003, p 9) 
In services, Seddon believes that the end-to-end flow of a service to customers can be understood as a system:

While all systems thinkers agree that a system is a sum of its parts and the parts must be managed as one, the Vanguard approach is unique in that it starts and ends with the work (Seddon 2003, p 177)

When, following Ohno, systems thinking is applied to the design and management of work, and that is set as the boundary for the activity, it is both interesting and profitable. The Vanguard approach sets a boundary. (Seddon 2003, pp 179)

Beginning with the placing of demand on a service and analysing its flow allows for a service to be studied as a system, much as W. Edwards Deming advocated with his famous 'Fig 1: Production viewed as a system' (see Fig. 3, below) diagram. It is therefore worth investigating a little more about two thinkers who had a major influence on Seddon's ideas: W Edwards Deming and Taiichi Ohno.

\section{Deming and Ohno: Two Systems Thinkers from Outside of the Mainstream}

W Edwards Deming (1900-93) was a distinguished management advisor to the Japanese during the American post-war reconstruction of their economy. He argued that Western organisations and thus Western economies were in crisis because of their beliefs in flawed management assumptions. His influence on Japanese manufacturing led to recognition by the Japanese Emperor in 1960, with the award of the Second Order Medal of the Sacred Treasure (Neave 1990). Deming finally found himself in demand in his native US when he was in his $80 \mathrm{~s}$, and wrote books and gave seminars for his new-found audience detailing his challenging ideas about management:

Most people imagine that the present style of management has always existed, and is a fixture. Actually, it is a modern invention - a prison created by the way in which people interact (Deming 1994, p 15)

Deming's thesis was that as man had invented this flawed form of management, man could reinvent it. His work (such as 1982's 'Out of the Crisis') detailed a critique of conventional Western management assumptions. In their place, he proposed that managers needed to understand and manage their organisations as systems. Deming's famous

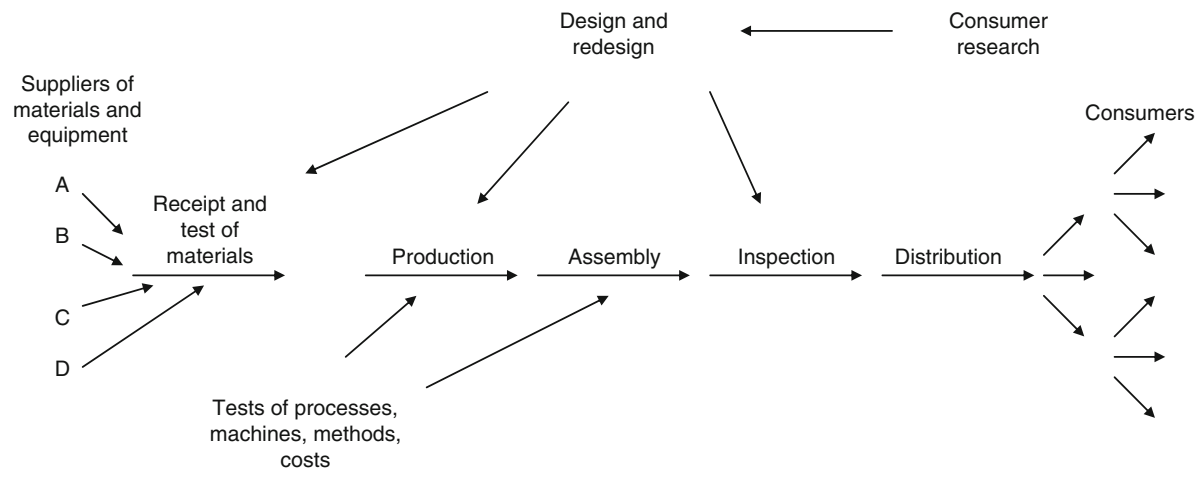

Fig. 3 Deming's famous 'Fig. 1' diagram: Production viewed as a system (Deming 1982, p 4) 
'Figure 1' diagram (1982, p 4) captured the flow of work through a manufacturing organisation.

Deming regarded this diagram as the most important diagram he ever drew in his life (Neave 2000, p 5). It demonstrated a system of production as Deming said:

The flow diagram was the spark that in 1950 and onward turned Japan around. It displayed to top management and to engineers a system of production. The Japanese had knowledge, great knowledge, but it was in bits and pieces, uncoordinated. This flow diagram directed their knowledge and efforts into a system of production, geared to the market-namely, prediction of needs of customers. The whole world knows about the results. This simple flow diagram was on the blackboard at every conference with top management in 1950 and onward. It was on the blackboard in the teaching of engineers. Action began to take place when top management and engineers saw how to use their knowledge. (Deming 1994, p 57)

Management's focus, argued Deming, therefore ought to be with the flow of work through the system as opposed to measuring and managing work in functional activities, as operating at this 'system' level achieves far more than focussing on the refinement of individual functions and/or processes.

Commenting on Deming's diagram, Henry Neave has said that there were two main aspects of importance:

Firstly, it is an all important horizontal view of how the work needs to get done what actually happens, and what needs to happen - in an organisation, rather than the familiar vertical view, which is just the power structure, the conventional organisation chart. And it is a very neat perspective that this vertical structure is so often obstructive to the horizontal flow. But it is that which is all-important regarding what the organisation actually does. And secondly, whereas the doing is represented by the arrows going from left to right in the flow diagram, the organisation should be continually improving - because of the learning and feedback represented by the arrows along the top going from right to left. And the vertical structure can be pretty effective at getting in the way of that as well! (Neave 2000, p 5)

Seddon shares this view that organisations need to be seen as a system, rather than as a series of functional activities (Seddon 2008, p 66).

Deming was critical of western management for what he saw as the absurdity of failing to understand that workers' performance was, in fact, governed by the extant system rather than individual performance:

The fact is that the system that people work in and the interaction with people may account for 90 or $95 \%$ of performance

(Deming in Scholtes 1998, p 296)

Certainly we need good results, but management by results is not the way to get good results. It is action on outcome, as if the outcome came from a special cause. It is important to work on the causes of results - i.e. on the system. Costs are not causes: costs come from causes

(Deming 1994, p 33)

If, as Deming claims, only $5 \%$ of performance is directly in the controllable domain and therefore the responsibility of the individual, it becomes significantly more important to consider the effects of redesigning the system that people work in rather than focussing 
on motivating the individual workers. Ideas such as these were affronts to the prevailing beliefs of conventional managers. He described how the costs of sub-optimisation created by the prevailing style of management were larger than mere production costs (such as poor quality or excess inventory), as they also incorporated human and societal costs (Deming 1982, p 127). He argued that the greatest costs of sub-optimisation are 'unknown and unknowable' (Deming 1982, p 121). Both the content (viewing work as systems) and the spirit of Deming's writings were influential on Seddon's systems thinking (Seddon 2003, p 9). The second major management pioneer from outside of the conventional systems literature to influence the Vanguard Method was Taiichi Ohno.

Taiichi Ohno (1912-90) was the architect behind the remarkable Toyota Production System, a system designed to produce cars at the rate of demand. Through necessity, Ohno had developed a contrasting approach to the mass production methods of US car firms. Ohno first realised a number of counter-intuitive truths in the $1950 \mathrm{~s}$, ideas that continue to challenge conventional management wisdom. Seddon argues that both Deming and Ohno's works showed the practical means to understanding work systemically. The most notable of these was to discover that costs were contained in the flow of work, not in creating economies of scale:

To think that mass-produced items are cheaper per unit is understandable, but wrong (Ohno 1988, p 68)

Ohno's innovation might be termed 'economy of flow' (Seddon and Caulkin 2007) as compared to economy of scale. Commenting on this distinction H Thomas Johnson said:

It is time to raise awareness of how production systems designed along the lines of Toyota's system turn scale-economy thinking completely on its head, making it possible to build manufacturing capacity on a much smaller scale than ever before thought possible. (Johnson 2003, p 7)

Elsewhere, he went further and said that 'scale economy, beyond very small volumes, is a concept that should be discarded' (Johnson 2008, p 102). It is only possible to see such counter-intuitive truths when viewing an end to end flow in either a production line (in Deming or Ohno's case) or a service (in Seddon's case) as a system. It is only then that another crucial systems characteristic, feedback loops (Senge 2006; Ison 2010) can be meaningfully incorporated to allow for continuous improvement.

An independent example of Toyota's work being called 'systems thinking' can be found in the practical experiences of the Toyota/General Motors joint venture NUMMI (New United Motors Manufacturing Inc.) in Fremont, California. This project demonstrated the necessity of taking a systems approach in a US manufacturing environment. As Cole says:

NUMMI demonstrated the 'importance of "systems" thinking' - the proper interrelationship of all factors that are part of the planning, design, production, selling, and servicing of vehicles and parts. In our culture, we tend to think in terms of narrow disciplines without appropriate linkages of the various elements of the production system. In a systems organization like NUMMI, there's tremendous attention to detail, but it's always integrated into the total system. Systems mentality is a very important success factor for the future. (Cole, in Ryan 1988, p 4)

Hence the operations management literature also refers to systems ideas, due in no small part to the seeds sown by Deming and Ohno. Their work has cast a long shadow over operations management, and should also be recognised as making a valuable contribution to systems thinking. Seddon's work has made these systems connections explicit. 


\section{Doing the Right Thing: Ackoff and Dissolving a Problem}

Russell Ackoff was a friend of Deming, and they discussed systemic thinking at length, believing that their works had a great deal in common (Ackoff and Deming 1992). This extract of a discussion between them shows their common ground:

Dr Ackoff: Now, in your writing about quality, you keep talking about the characteristics of the system as a whole, that unless you get that right, unless the system is right, improving the quality of the parts taken separately will not necessarily improve the quality of the output of the system.

Dr Deming: Yes. I try to ... I try to say that. I try to teach that.

Dr Ackoff: Yes. The other thing that you do, which I think is very important, is the systemic concept, is you point out that getting rid of what you don't want is not equivalent to getting what you do want; that improvement has to be directed towards what you want, not away from what you don't want.' (Ackoff and Deming 1992, p 15)

Seddon's Vanguard Method was also designed to lead people to a position where they were able to work towards achievement of 'what they do want' - the steps that would allow the organisation to satisfy the demands of service users. In turn, by working towards a new purpose in this way, quality can be improved in the system as a whole as Deming taught. Ackoff argues that the problems indicated from the first analysis of a situation should not be directly solved, but instead should be 'dissolved':

Dissolution consists of eliminating a problem, preventing it from arising again by redesigning the system that has the problem or its containing system. Problem dissolvers try to idealize, to do better in the future than the best that can be done today. They recognize that in a turbulent environment problems do not stay solved and that their solutions often generate a number of new and more difficult problems. Problem dissolution avoids both these consequences (Ackoff et al. 2006)

A direct comparison can be made with the Vanguard stage of going through Check, which helps managers to see how the various parts of the service work (or do not work) together towards a purpose. As a result, managers often come to realise that the problems they thought they had to solve are not actually the causes of sub-optimal performance: their problems are dissolved. For example, managers in children's social care think they have too much demand coming into their organisation, and want to know how best to 'screen out' cases of lesser seriousness. However, studying the system shows that up to $70 \%$ of demand is actually made up of cases that were not dealt with right first time before. By redesigning to deal with cases right first time, the capacity of the system immediately improves and the need to screen out cases disappears (See Gibson and O'Donovan 2012, paper in this special issue).

\section{Worldviews and the Ontology of a System}

Seddon says little about whether systems exist a priori or whether, as other systems theorists have believed, the system only becomes constituted once someone has conceived of a situation as a series of connected parts. For Seddon, the important thing is that, within these service organisations, the parts combine to produce a particular purpose, whether desired or not. It is therefore important to expose the reasons why the system performs in the way it does. 'Check' therefore is the stage of 'getting knowledge' about how the system 
works for service users before any attempt has been made to redesign it: what it looks like, how it performs and what thinking is driving the current design of the system. Churchman (1968) and Checkland (1981) both talk about the concept of 'Weltanschauung,' taken from German philosophy and meaning an individual's worldview, based as it is on an individual's particular mental model of the world. There are many possible, alternative worldviews constructed on various sets of taken-for-granted assumptions held by different people at different points in time (Jackson 2003, p 139). As Ackoff says, 'It is in the nature of systemic thinking to yield many different views of the same thing and the same view of many different things.' (Ackoff in Flood 1999) Going through the 'Check' process involves the idea of people being exposed to their own 'Weltanschauung' and recognising that this often contrasts with the experience of their service from a customer's perspective. As we have discussed above, Ackoff might describe going through the 'Check' process as 'formulating the mess' so that it can be 'dissolved':

The best thing that can be done to a problem is to dissolve it, to redesign the entity that has it or its environment so as to eliminate the problem. (Ackoff 1999b)

Importantly in Seddon's work, once such an understanding of the current state caused by the command and control thinking in an organisation is gained, there is no 'to-be' future state for the service which is being redesigned. Whilst the process of Check does give a picture of the current state, the redesigned process is continually being improved by the workers and managers who work in it. During the examination of the flow of work in Check, the people in the organisation identify the value steps in the process. By aiming to achieve an ideal system where only these few value steps take place, the organisation attempts to 'learn the art of the possible in pursuit of perfection' and is continually looking to create an effective system. This is in line both with Ackoff's comment to Deming above ('improvement has to be directed towards what you want, not away from what you don't want') and with Taiichi Ohno's pronouncement that they were continually in search of perfection at Toyota:

"All we are doing is looking at the time line," he said, "from the moment the customer gives us an order to the point when we collect the cash. And we are reducing that time line by removing the non-value-added wastes." (Ohno 1988, p 9).

Therefore, learning that takes place in the experimentation of redesign is emergent, involving trial-and-error (i.e. with new methods of providing a service). In embracing this emergent approach to change, Seddon's Vanguard model is also positioned firmly in the systems thinking tradition:

The idea of emergent properties is the single most fundamental systems idea and to

use this (and other) systems ideas in a conscious organised way is to do some

'systems thinking' (Checkland 1997, cited in Chapman 2002)

The Vanguard Method is therefore embedded in another systems tradition, that of experiential learning.

\section{The Necessity for Experiential Learning}

Ison writes that 'my experience, and that of my colleagues, is that systems thinking and practice is best learned experientially' (Ison 2010, p 18). When service organisations are studied as systems, they reveal similar counter-intuitive phenomena to those found by Ohno in the Toyota Production System. The Vanguard Method enables service managers 
to study their work as a system, and along the way have normative (Chin and Benne 1969) experiences which help them to change the way they think about their work. There are two main theoretical components to the Vanguard Method: systems theory (which shows how organisations work) and intervention theory (which teaches people how to make a successful change). In fact, the intervention theory taught as part of the Vanguard Method is also connected to the systems literature through the work of Argyris and Schön. It therefore has many distinctive features: it both teaches people how to study their service as a system and leads them through a process of double loop learning (Argyris and Schön 1974). Seddon describes the need to 'unlearn' before one can 'learn' the new way that a system should work, in an 'emergent, adaptive' approach to change.

Systems thinking is only truly learned by doing, by action learning: it is only by doing that managers can unlearn, can find out for themselves where their current beliefs about the design and management of work are flawed, in order to put into place something that works systematically better, and can systemically be further improved (Seddon and Caulkin 2007)

Figure 4 shows this double-loop learning represented diagrammatically.

Only by working in this way can the 'governing variables' behind management actions be surfaced and subsequently altered.

Single-loop learning occurs when matches are created, or when mismatches are corrected by changing actions. Double-loop learning occurs when mismatches are corrected by first examining and altering the governing variables and then the actions. (Argyris 1999, p 68)

This guidance on how to become a learning organisation also links the Vanguard Method to the aspirations of another noted systems thinker, Peter Senge (Seddon and O’Donovan 2010). Senge defined learning organisations as:

... organizations where people continually expand their capacity to create the results they truly desire, where new and expansive patterns of thinking are nurtured, where collective aspiration is set free, and where people are continually learning how to learn together. (Senge 2006, p 3)

Seddon claims that the Vanguard Method provides a route for organisations to become:

a learning, improving, innovative, adaptive and energised organisation. It provides the means to develop a customer-driven adaptive organisation; an organisation that behaves and learns according to what matters to customers (Seddon 2003, p 179)

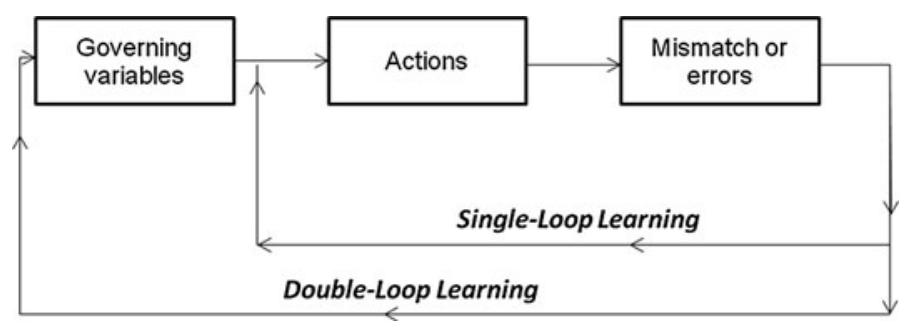

Fig. 4 Double-loop learning (from Argyris 1990, p 94) 
In 2010, Portsmouth council's housing department won an award from US management expert Gary Hamel for exemplifying just such a learning, adaptive organisation. The council were able to deliver housing repairs at the time the customer wanted them whilst reducing the cost of the service by half (Hamel and LaBarre 2010). They achieved this by working directly to two factors: delivering against the system's purpose and measuring how well the service performed the task of providing what mattered to their customers. The associated ideas that (a) there is a need to pay attention to the purpose of a system and then (b) to construct a system that delivers exactly what the customer wants warrant further examination, and will be covered in the section on 'requisite variety' below.

\section{The Purpose of a System}

Jackson, debating the merits of the Vanguard Method, says that it 'successfully embodies various systems principles' (ODPM 2005) in the way it is applied to service organisations.

The Vanguard approach is careful to start with the purposes of the system and does so in terms of its customers - 'what matters is what matters to the customer'... Having clarified the customers' purposes, a customer perspective can be maintained throughout a project, guiding all aspects of system and subsystem design, and evaluation. (ODPM 2005, p 65)

This focus on defining and working to a purpose is a characteristic of systems thinking and practice. The Open University primer on systems thinking says 'a system is a set of things interconnected for a purpose ... when you are confronted with a set of components and you want to find ways of working with them, or making them work better, it is always useful to look at them as if they had a purpose' (Open University 1999). There are some similarities between Seddon's 'purpose,' Checkland's 'root definition' (Checkland 1981) and Ackoff's 'mission statement' (Ackoff 1999a) as the formative steps in 'dissolving the mess.' The Vanguard 'ideal state' may be similar to Ackoff's 'idealized design' (Ackoff et al. 2006): only doing the value steps in the Vanguard model and the idealized design are both things to aim for, even if they are never actually achieved. In the Vanguard Method, there is much discussion about the purpose of a system as seen from a customer's perspective: it is the first step in the model for Check (Seddon 2008, p 79). As a consequence of studying a system, it is common for people to identify that the system is working to an unintended, de facto purpose before redesigning it against a purpose as defined by the customer. This de facto purpose is normally internally focused and relates to the performance of the organisation against centrally defined targets. In fact, Seddon talks about the systemic relationship between the purpose, measures and method of an organisation (see Fig. 5).

In a command and control world, central control and management by targets creates a de facto purpose for a system, which also constrains the ability of the workers to experiment with the method for performing the tasks required to provide a service. Seddon's (2003) theory says that for workers to be able to continuously improve, they need to be able to experiment with the best method of service delivery. In order that the method by which work is done can be liberated, there is a need for measures which are helpful in saying which method is more efficacious than another. In turn, these measures must be related to the purpose of the exercise: does the work undertaken achieve what it was meant to? 


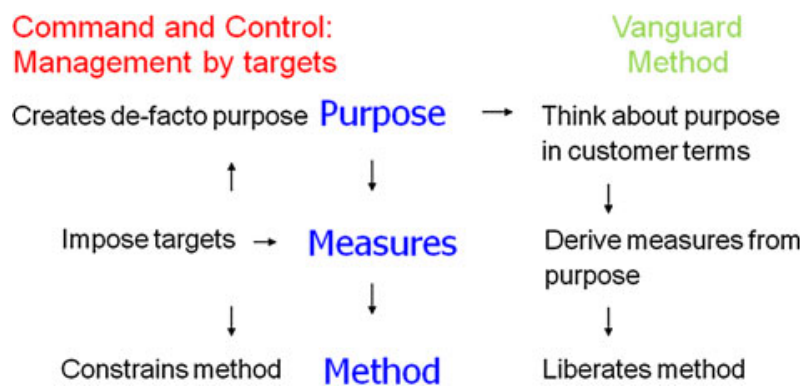

Fig. 5 Purpose, measures and method, contrasting command and control management with that of the Vanguard Method (adapted from Seddon 2003, p 62)

\section{Requisite Variety}

If services are constrained by arbitrary, fixed measures, then they cannot produce service which matches the level of variety with which they are required to deal, and thus they fall foul of Ashby's 'law of requisite variety' (Ashby 1958). According to early systems thinker William Ross Ashby, systems can only be viable if they can command the same degree of variety as their environments. Managers therefore need to pay attention to reducing external variety where possible, and to increasing the variety of the system they control. The conventional arguments of the operations management literature concentrate on reducing variety on the producer's side (see the arguments for standardization by managers as expounded by Levitt 1972; Womack et al. 2007 and many others in the literature). However, services have been defined as distinct because they are produced and consumed simultaneously, with the customer participating in the production process (Grönroos 1990). This greater level of interaction with the customer means that services are subject to more variety than manufacturing (Seddon 2003, p 77). In services, Seddon argues that systems need to be designed in such a way as to be able to provide 'requisite variety' in order to satisfy the customer's 'nominal value' (Seddon 2003). Nominal value is a term most closely associated with Genichi Taguchi who challenged the idea of working to 'standards' or 'within tolerances' in manufacturing. Instead of following these arbitrary standards, Taguchi believed it would be better to set a nominal value and work to continually reduce variation, resulting in better quality and lower cost (see Fig. 6).
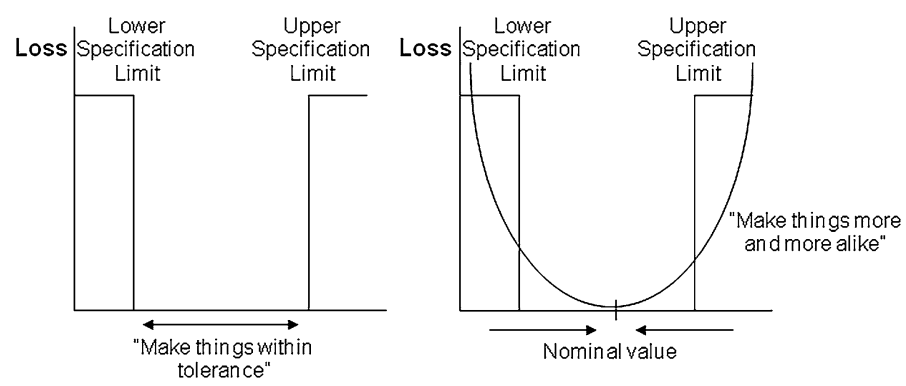

Fig. 6 Diagrams showing the contrast between the traditional method of interpreting manufacturing limits and Taguchi's Loss Function 
A tentative nominal value is then 'tested over specified ranges during parameter design, and the best combination of levels is determined ... This is the key step for achieving high quality without an increase in cost' (Byrne in Ryan 1988, p 17). As Neave says, the loss function 'keeps in our minds the necessity for continual improvement-if there are discrepancies from nominal (and there always will be), then loss is being incurred, so the need for improvement (reduced variability) is ever-present.' (Neave 1990, p 175) It is both the concept of nominal value and the empirically informed way of working to continually improve to ultimately achieve this ideal which Seddon has incorporated into his theory for managing services. In service industries, Seddon thinks that the customer sets the nominal value (Seddon 2003, p 60). If an organisation does not recognise and respond to what matters to the customer, then the customer's experience of the service is poorer and the organisation is forced to consume extra resources to resolve the situation of disaffected customers. One of Seddon's major innovations is the identification of the two major categories of demand hitting organisations: value demand (demand the organisation exists to serve) and failure demand 'demand caused by a failure to do something or do something right for the customer' (see Seddon 2003, p 26). To allow the workers enough freedom to provide the requisite variety to match customer value demands (and to avoid the creation of failure demand), the locus of control in the work must remain with that worker. In itself, this leads us back to the idea that systems must have a purpose: systems redesigned using Vanguard's principles are working to the purpose of the system, using measures that relate to the achievement of successful delivery of what matters to customers.

\section{Feedback Loops}

Jackson attributes the systems concept of feedback loops to Norbert Wiener (1894-1964), an early pioneer of cybernetics:

It was Wiener's insight that all such behaviour requires negative feedback. In this process, information is transmitted about the divergence of behaviour from a present goal and corrective action taken, on the basis of this information, to bring the behaviour back towards the goal. (Jackson 2003, p 7)

Jackson goes on to explain how Jay Forrester (1918-) and particularly Peter Senge (2006) popularised these ideas of feedback in their work on system dynamics. The Vanguard Method, where appropriate, incorporates immediate feedback from users in order to improve the systems once the purpose of the system has been achieved using a simple two step process. For example, where a repair has been completed in a social housing setting, residents are asked by an agent (perhaps either a tradesman or a call centre operator who dealt with the repair) immediately to score the service they have received out of ten. If the mark is lower than eight, they are asked 'what could we have done better to turn your score into a ten?' In this way, that customer's nominal value is elicited. Feedback is then formally incorporated back into improving the system for the future at regular discussions between workers and their managers. There are also feedback loops operating in this system in other ways, such as where the tradesman performing the repairs continually reviews the type and frequency of the materials being used. It is often discovered that inventory has been retained for 'just-in-case' purposes. Instead, stock levels can be maintained for the future based on actual demand for particular items, rather than through rough estimates. As Jackson says: 
In that sense the Vanguard approach is self-evaluating. A benefit is that customers are immediately involved in evaluating, and helping to improve, something of immediate significance to them. They are not vaguely consulted through questionnaires or focus groups. It is also seen as important that evaluations are fed back directly to those operating the system. (Jackson in ODPM 2005, p 67)

As has been shown, there are many aspects of the Vanguard Method which can be seen as in common with other systems theories. However, Jackson has also offered a critique of the Vanguard Method, especially in relation to the way it deals with the primacy of subsystems' claims on the larger system.

\section{Jackson's Criticism of the Vanguard Method}

Criticisms have been made of the Vanguard Method for its narrow focus on the system as defined by the customer of a service. Jackson (ODPM 2005, p 68) said that the Vanguard Method allows for sub-systems to be redesigned without attention to the higher, macrolevel systems until they appear as constraints on the achievement of the purpose of the subsystem.

There is a well-known systems principle that we should plan simultaneously and interdependently for as many parts and levels of a system as possible (Ackoff 1999a). [The Vanguard Method] seems willing, however, to redesign sub-systems with little reference to other parts or levels. Optimizing the performance of just one sub-system risks the danger of 'sub-optimization.' Sub-optimization refers to the possibility that apparent improvements in one sub-system might make the performance of the whole system worse. It arises because of the importance of the interactions between the parts in complex systems. [The Vanguard Method] recognizes issues of sub-optimization at the system level at which it is operating but pays less attention to them at the wider system level. (Jackson et al. 2008, pp 10-11)

It is correct that Seddon is clear that the boundary of the system to be studied must be set by the customer, and a unique element of the Vanguard Method is that it starts and ends with the work (Seddon 2003, pp 177-9). Jackson believes this may lead to overall suboptimisation in the higher level system. In practice however, the Vanguard Method firstly seeks accommodation with higher level systems, treating constraints of the higher system as 'system conditions' (causes of waste in a system that explain why it behaves in the way it does) and then later attempts to instigate change at this higher level where it is possible. For example, an umbrella organisation for welfare advice organisations (Advice UK 2009) studied the workings of some of its members and established that it was costing advice organisations from across the country a minimum of $£ 500$ million to mop up failure demand downstream from HMRC, the UK government tax office. After gathering evidence of the costs of failure through localised Vanguard interventions, Advice UK has subsequently been directly lobbying HMRC/the government for change. In another instance, interventions in local authority food safety departments showed how inspection by the Food Standards Agency (FSA) was impairing the ability of the system to achieve its purpose of 'going out and ensuring businesses are producing safe food. ${ }^{1}$ Here, a local authority engaged with the FSA to the extent that the FSA began working to support the

\footnotetext{
${ }^{1}$ See http://www.thesystemsthinkingreview.co.uk/index.php?pg=18\&utwkstoryid=329 (accessed 16.12.11).
} 
experimentation with better methods for doing food safety work that were ongoing at the council involved. Returning to Jackson's point then, it is fair to say that the Vanguard Method teaches initial accommodation of these outside causes of sub-optimisation in the short-term, but it returns to address them once the micro-level system has been improved and made stable. Jackson also says that the Vanguard Method neglects consideration of multiple perspectives of the purposes of the system:

The apparent neglect of multiple possible purposes, in the Vanguard approach, may see it closing down interesting and creative possibilities for rethinking purposes. It can also require a lot of effort to be devoted to keeping on side those who, for whatever reason, do not share the explicit purposes that are articulated (ODPM 2005, p 70)

Jackson's observation is correct: Seddon is clear that the Vanguard Method prioritises the purpose as defined by the customer rather than looking at the system from multiple perspectives. However, Seddon's view is that the interests of other stakeholders should be accommodated through better design of the system. For example, in the private sector, these stakeholders may be shareholders who benefit from a more profitable enterprise, whilst in the public sector policymakers benefit when public services are optimised. Anyone attempting to intervene at the level of the higher system would risk working without knowledge: by starting at a sub-system level, one studies the work taking place in situ to understand the true problems from the customer's point of view. If one were to prioritise solving the perceived problems of the stakeholder, this would involve acting without first studying and would be at the expense of understanding the system from the customer's point of view.

\section{Conclusion, and Introduction to the Rest of the Special Edition}

The discussion above has shown that the Vanguard Method, when applied to service organisations, embodies many systems principles. As has been argued, it emphasises the need to see the whole rather than manage the parts, it opposes reductionist methods, it helps managers to 'dissolve' the problems they thought they had, it incorporates the idea of emergent properties, it stresses the need for experiential learning, it recognises (and sharpens the focus on) the purpose of a system, it designs for requisite variety and develops feedback loops. These features therefore suggest the Vanguard Method has a strong claim to belong in the tradition of other systems theories. The influences of Deming, Ohno and Taguchi are all unconventional reference points, although they only serve to reinforce the systems principles in Seddon's work.

All of the systems thinkers mentioned here developed their models in relation to the context they found themselves in. For example, Checkland's method was devised for solving complex management problems (for example, like those he encountered when working as a consultant on the Concorde project) and has been proposed for use when developing policy at government level (Ramage and Shipp 2009). Ackoff's 'Idealized Design' ideas (Ackoff et al. 2006) were aimed at advising an organisation which wishes to strategically plan its future direction, working at the system level.

The Vanguard Method is different in that it was developed to structure interventions and improvement in service organisations who wish to find 'a better way to make the work work' (Seddon 2003) by first moving them away from command and control thinking and subsequently redesigning their services according to systems principles. Seddon himself 
differentiates his work from other systems theorists by referring to a statement by Stafford Beer:

\begin{abstract}
Although we may recognise the systemic nature of the world, and would agree when challenged that something we normally think of as an entity is actually a system, our culture does not propound this insight as particularly interesting or profitable to contemplate (Beer 1974, p 3)
\end{abstract}

\title{
Seddon states:
}

When, following Ohno, systems thinking is applied to the design and management of work, and that is set as the boundary for the activity, it is both interesting and profitable. The Vanguard approach sets a boundary. Other approaches to systems thinking might be interesting but not, in my experience, profitable. The Vanguard approach is interesting and profitable. Interesting, because it provides a method for developing relevant knowledge and, consequently, achieving the ideals all managers would aspire to: a learning, improving, innovative, adaptive and energised organisation. Profitable, because it provides the means to develop a customer-driven, adaptive organisation; an organisation that behaves and learns according to what matters to customers. If the system is to have viable economics, it could only be understood and developed from this point of view. (Seddon 2003, p 179)

It is this simple approach to setting boundaries which allows practitioners to navigate their way through vastly complex areas such as the British healthcare system: by allowing the path of the patient to set the boundary of the investigations through the provision of care by multiple agencies (hospitals, local authorities, mental health trusts, housing associations, charities) it allows for the efforts of the teams to be 'profitably' focussed on transforming these various systems for the better. As such, Seddon is correct to characterise the Vanguard Method as both 'interesting' in the remarkable things it discovers from this customer-centred point of view and 'profitable' in terms of practically being able to redesign such a system around its purpose from a customer's perspective.

A particular systems characteristic which is unique to the Vanguard Method is the relationship between the elements of 'Thinking, Systems and Performance' (Seddon 2003, $\mathrm{p}$ 10). For Seddon, it is critical that the mindset of the people within a system changes as a prerequisite for their redesigned system to achieve sustained levels of superior performance (see Fig. 7).

The necessity for managers to change the way they think is the common theme that links all of the articles that follow in this special issue. For example, systems designs challenge the current norm of 'dumbing-down' service (hire cheap people, give them scripts and computer-based diagnostics). Instead the Vanguard approach can be characterised as 'smartening-up'; people who deliver services need the expertise required to identify and deal with the variety of customer demands. The managers in the organisations

Fig. 7 The relationship between thinking, systems and performance (Seddon 2003, p 10)

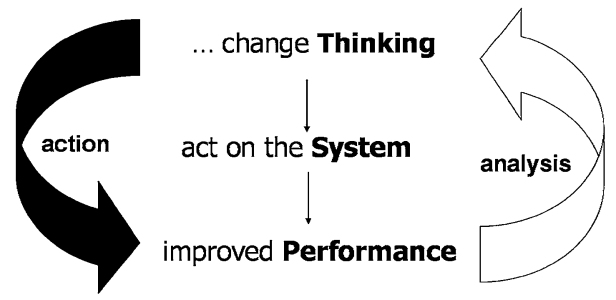


covered in the following articles discovered that the dominant beliefs in command and control methods were actually distorting their systems away from being able to deliver what their customers wanted. Only by taking time to study were they able to recognise the need to change the way they previously thought about their organisations, which in turn allowed them to change their systems and improve their performance.

The first article presents an alternative view of how to transform the way that the higher education system delivers service to students in an environment where 'student choice' will be viewed as of paramount importance in the future. Along the way, the team managed to reduce the turnaround time for university applications from an average of 48 days down to 3 days, whilst doubling the number of people who rated the service as 10/10.

In the second article, an account is given of the learning that has taken place from moving to a new, systems way of working in children's services departments. The article is particularly relevant in the light of the government commissioned Munro Review of child protection in England and Wales, which recommended that systems principles should be applied in this area of complex human relationships.

The third article is written by the chief executive of a social enterprise which provides support to people with learning difficulties. He describes what he learnt by studying his system from a service user's point of view, and the innovative means by which the organisation now works with users to understand and measure progress towards their aspiration for 'a good life.'

Finally, the last article is a manager's reflection upon the applicability of the Vanguard Method in a manufacturing environment, and what the organisation would learn if it followed the method and redesigned its operations. It concludes that 'command and control' is just as prevalent and damaging in a manufacturing environment.

Returning to Deming, we know that he described conventional management as a 'prison,' although it was a 'modern invention' which was not a 'fixture' (Deming 1994, p 15). Collectively, these papers provide us with the heartening news that there are plenty of organisations determined to prove that modern management can be reinvented. There was no obligation on the organisations featured in the following articles to pursue the tired old paradigm where targets were used to control workers and where managers spent their time analysing variation from budgets. The cases featured in this special issue show how organisations have managed to buck the trend and instead placed true 'knowledge workers' at the forefront of the design and improvement of their organisations.

\section{References}

Ackoff R (1999a) Re-creating the corporation: a design for organisations in the 21st century. Oxford University Press, New York

Ackoff R (1999b) On passing through 80. Syst Pract Action Res 12(4):425-430

Ackoff R, Deming WE (1992) A theory of a system for educators and managers' dowloaded from http://ackoffcenter.blogs.com/ackoff_center_weblog/2011/04/a-converstaion-between-russellackoff-and-edward-deming.html on 20/7/12

Ackoff R, Magidson J, Addison H (2006) Idealized design. University of Pennsylvania, Wharton

Advice UK (2009) Interim report: radically rethinking advice services in Nottingham. AdviceUK, London Argyris C (1990) Overcoming organizational defences: facilitating organizational learning. Allyn and Bacon, Boston

Argyris C (1999) On organisational learning. Blackwell, London

Argyris C, Schön D (1974) Theory in practice: increasing professional effectiveness. Jossey-Bass, San Francisco 
Ashby WR (1958) Requisite variety and its implications for the control of complex systems. Cybernetica 1(2):83-99

Beer S (1974) Designing Freedom. Anansi, Toronto

Capra F (1996) The web of life: a new synthesis of mind and matter. Flamingo, London

Caulkin S (2010) Managing for the better. Downloadable from http://www.systemsthinking.co.uk/6-leaderssummary.asp

Chapman J (2004) System failure. Demos, London

Checkland P (1981) Systems thinking systems practice. Wiley, Chichester

Checkland P (1997) Systems. In: International Encyclopaedia of Business and Management. Thomson Business Press

Chin R, Benne KD (1969) General strategies for effecting changes in human systems. In: Bennis WG, Benne KD, Chin R (eds) The planning of change, 2nd edn. Holt, Rinehart and Winston Inc, USA

Churchman CW (1968) The systems approach. Delacorte Press, New York

Deming WE (1982) Out of the crisis. MIT Press, MA

Deming WE (1994) The new economics: for industry, government education. MIT Press, MA

Flood R (1999) Rethinking the fifth discipline, learning within the unknown. Routledge, London

Gibson J, O'Donovan B (2012) The Vanguard Method as applied to the design and management of English and Welsh Children's Services departments. Syst Pract Action Res (Special Issue on the Vanguard Method)

Grönroos C (1990) Service management and marketing. Lexington Books, Lexington

Hamel G, LaBarre P (2010) Dispatches from the front lines of innovation management. McKinsey Quarterly (1): $118-123$

Ison R (2010) Systems practice: how to act in a climate change world. Springer, Open University, Milton Keynes

Jackson M (2003) Systems thinking: creative holism for managers. Wiley, Chichester

Jackson M, Johnston N, Seddon J (2007) Evaluating systems thinking in housing. J Oper Res Soc 59:186-197

Johnson HT (2003) Restoring the human side of economic enterprise: can humanity survive the financial dictatorship of business? Paper delivered at Meijo University 31/05/03

Johnson HT (2008) 'Lean management and true sustainability' in the lean manufacturing yearbook 2008. Society of Manufacturing Engineers, Michigan

Levitt T (1972) Production-line approach to service. Harv Bus Rev 50(5):41-52

Middleton P (ed) (2010) Delivering public services that work (Volume 1): systems thinking in the public sector-case studies. Triarchy Press, Axminster

Neave H (1990) The Deming dimension. SPC Press, Tennessee

Neave H (2000) A summary of teachings to top management and to engineers in Japan. The Swiss Deming Institute. Downloadable from http://www.deming.ch/downloads/better_future.pdf

Office of the Deputy Prime Minister (ODPM) (2005) A systematic approach to service improvement evaluating systems thinking in housing. ODPM publications, London

Ohno T (1988) Toyota production system. Productivity Press, Portland (translated from Japanese original, first published 1978)

Open University (1999) Systems thinking and practice: a primer. Open University Press, Milton Keynes

Ramage M, Shipp K (2009) Systems thinkers. Open University, Milton Keynes

Ryan N (ed) (1988) Taguchi methods and QFD: hows and whys for management. ASI Press Dearborn, Michigan

Scholtes PR (1998) The leader's handbook: making things happen, getting things done. McGraw-Hill, London

Seddon J (2003) Freedom from command and control. Vanguard Press, Buckingham

Seddon J (2008) Systems thinking and the public sector. Triarchy, Axminster

Seddon J, Caulkin S (2007) Systems thinking, lean production and action learning. In: Action learning research and practice vol 4, no 1, special issue: Lean Thinking and Action Learning

Seddon J, O'Donovan B (2010) Why aren't we all working for Learning Organisations? AMED e-Organisations and People, vol 17, no 2

Senge P (2006) The fifth discipline. Random House Business Books

Taylor FW (1998) The principles of scientific management. Dover Publications, New York (first published in 1911)

The Systems Thinking Review 'It is safer to eat out in Great Yarmouth today-three cheers for a new model of regulation!' http://www.thesystemsthinkingreview.co.uk/index.php?pg=18\&utwkstoryid=329 (accessed 16.12.11) 
Tuckman A (1994) The yellow brick road: total quality management and the restructuring of organizational culture. Organ Stud 15(5):727-751

Womack J, Roos D (2007) The machine that changed the world. Simon and Schuster, London (first published in 1990)

Zokaei Z, Elias S, O’Donovan B, Samuel D, Evans B, Goodfellow J (2010) Lean and systems thinking in the public sector in Wales. Lean Enterprise Research Centre report for the Wales Audit Office, Cardiff University 